\title{
DESAIN MODEL PEMBELAJARAN ONLINE SEBAGAI UPAYA MEMFASILITASI BELAJAR DI TEMPAT KERJA
}

\author{
Syaiputra Wahyuda Meisa Diningrat \\ STIT Al-lbrohimy Bangkalan \\ e-mail:
}

\begin{abstract}
Vocational high school in Indonesia is familiar with the concept of dual system education program. There are two places of learning such as school-based learning and work-based learning. A few vocational education institutions have claimed that during carry out workbased learning, they ask students to master some competencies through self-regulated learning without a learning environment that planned. Therefore, this article aims to give an integrative learning design framework for online learning as an effort to guide educators and instructional designers in designing and developing online learning environment that meet with the students need. Shifting roles of educators and instructional designers in online learning, each component within integrative learning design framework for online learning, as well as the features of online learning model are discussed here. So that, educators and instructional designers who want to design online learning model could not only avoid mistakes but also reduce the failure.
\end{abstract}

Keywords: Design Online Learning Model, Effectiveness, Pendidikan Kejuruan

\section{PENDAHULUAN}

Dalam Pendidikan Sistem Ganda (PSG) terdapat dua kegiatan belajar, yaitu kegiatan belajar di sekolah (school-based learning) dan kegiatan belajar ditempat kerja (work-based learning) Bukit (2014: 43). Kegiatan prakerin atau praktek kerja industry merupakan bentuk nyata dari penerapan PSG, di mana peserta didik melakukan aktivitas pembelajaran di tempat bekerja selama beberapa bulan dan kembali ke sekolah ketika kegiatan tersebut telah selesai.

Beberapa sekolah mengklaim bahwa selama kegiatan prakerin, peserta didik dituntut untuk tetap melaksanakan kegiatan belajar secara mandiri. Hasil kegiatan belajar mandiri yang dilakukan selama mengikuti prakerin akan dibuktikan melalu hasil ulangan harian atau ulangan tengah semester. Bagaimanapun juga, terdapat beberapa sekolah yang tidak menuntut peserta didik nya untuk mempelajari materi secara mandiri, dengan kata lain dibebaskan dari tuntutan belajar.

Artikel ini akan membahas tentang bagaimana merancang model pembelajaran online yang sesuai kebutuhan peserta didik sebagai upaya memfasilitasi belajar bagi mereka yang sedang melaksanakan kegiatan praktek kerja industri, mengingat tempat mereka melaksanakan prakerin cukup jauh dari sekolah, namun tetap dituntut untuk menguasi materi pembelajaran dengan cara belajar secara mandiri tanpa ada lingkungan belajar yang terstruktur.

Ally Mohamed (2008: 17) menjelaskan beberapa manfaat pembelajaran online. Pertama, keterbatasan jarak, tempat, dan waktu menjadi tidak berarti lagi, sebab mereka dapat belajar di mana saja, kapan saja, meskipun berada jauh dari tempat sekolah. Kedua, mampu menyediakan ruang berinteraksi antara pendidik dan peserta didik, sehingga pendidik mampu memberikan bantuan belajar bagi peserta didik yang membutuhkan. Bagaimanapun juga, model pembelajaran online yang 
efektif, memerlukan perencanaan yang tepat dan sesuai dengan prinsip pembelajara, sehinga terciptalah lingkungan belajar efektif, terstruktur, terarah, dan memiliki tujuan yang jelas.

Oleh karena itu, sebagai upaya memfasilitasi belajar mandiri peserta didik melalui desain model pembelajaran online yang efektif, dalam artikel ini akan disajikan beberapa landasan teori mengenai konsep pembelajaran online, kompetensi pendidik dan peserta didik dalam pembelajaran online, serta kerangka desain model pembelajaran integratif dalam pembelajaran online.

\section{PEMBAHASAN}

\section{Apa itu Pembelajaran Online?}

Secara sederhana pembelajaran online, jika dilihat dari tipe model pembelajaran Allen dan Seaman, dapat di artikan sebagai program pembelajaran yang hampir sebagaian atau semua materi belajar dikirimkan secara online (Ellen dan Seaman, 2007:4), untuk lebih jelasnya perhatikan Tabel 1.

Tabel 1. Tipe Model Pembelajaran

\begin{tabular}{|c|c|l|}
\hline $\begin{array}{c}\text { Proporsi Penyampaian } \\
\text { materi secara online }\end{array}$ & Tipe Pembelajaran & \multicolumn{1}{|c|}{ Deskripsi } \\
\hline $0 \%$ & Tradisional & Model pembelajaran tanpa online. \\
\hline $1-19 \%$ & Pembelajaran Web & Model pembelajaran berbasis web. \\
\hline $30-79 \%$ & $\begin{array}{l}\text { model pembelajaran dimana materi } \\
\text { belajar sebagian disampaikan melalui } \\
\text { tatap muka dan sebagian lagi melalui } \\
\text { online. }\end{array}$ \\
\hline $80 \%$ & Online & $\begin{array}{l}\text { Model pembelajaran di mana hampir } \\
\text { seluruh materi belajar disampaikan } \\
\text { melalui online, dan tidak ada } \\
\text { pertemuan tatap muka. }\end{array}$ \\
\hline
\end{tabular}

Menurut Harasim (2012: 27), jika dilihat dari dimensi alat penyampai, pembelajaran online diartikan sebagai penggunaan jaringan komunikasi online dalam aktivitas belajar, seperti mengirim dan mengakses materi belajar, yang dimediasi oleh portal web. Konsep tersebur menunjukkan bahwa dalam pembelajaran online terdapat beberapa unsur utama, yakni jaringan internet dan portal web. Dengan kata lain, tanpa tersedianya dua komponen tersebut mustahil dapat terwujud model pembelajaran online.

Tidak jauh berbeda dengan pendapat di atas, menurut Dabbagh dan Bannan-Ritland (2005:15), jika dilihat dari pedagogik, pembelajaran online didefinisikan sebagai lingkungan belajar terbuka dengan memanfaatkan jaringan internet dan teknologi web untuk memfasilitasi belajar, membangun pengetahuan melalui aktivitas dan interaksi belajar yang bermakna. Tidak jauh berbeda dengan pendapat Harasim bahwa komponen utama pembelajaran online adalah pemanfaatan jaringan internet dan teknologi web. Namun, dalam definisi ini telah ditunjukkan bahwa tidak hanya berfokus pada fasilitas atau alat yang digunakan dalam pembelajaran online, akan tetapi perencanaan berdasarkan model pedagogik, dan aktivitas belajar dan berinteraksi yang bermakna juga perlu diperhatikan.

Oleh karena itu, sebagai upaya memfasilitasi pembelajaran secara online, pendidik dan desainer pembelajaran perlu memiliki kemampuan dalam merancang dan mengembangkan kegiatan 
dan interaksi belajar yang bermakna melalui desain model pembelajaran online yang sesuai dengan kebutuhan peserta didik.

\section{Karakterisitk Model Pembelajaran Online}

Dalam artikel ini akan disajikan 5 karakteristik utama dalam model pembelajaran online menurut Diningrat (2016).

1. Aktivitas pembelajaran dimediasi oleh portal web melalui jaringan internet.

2. Tersedianya berbagai jenis interaksi, seperti: Pendidik dan peserta didik, pendidik dan materi pembelajaran, peserta didik dan materi pembelajaran, serta peserta didik dan peserta didik lainnya.

3. Terciptanya komunikasi dua arah.

4. Keterbatasan jarak, lokasi, dan waktu bukan menjadi permasalahan.

5. Terdapat dua jenis komunikasi, yaitu synchronous (tatap muka) dan asynchronous (tanpa tatap muka).

Berdasarkan karakteristik di atas, muncul kompetensi baru yang harus dimiliki oleh pendidik dan peserta didik dalam mengimplementasikan pembelajaran online. Oleh karena itu, sebagai akibat pergeseran lingkungan belajar dari tatap muka ke lingkungan belajar online, diperlukan keterampilanketerampilan yang dapat mendorong keberhasilan kegiatan pembelajaran secara online, selanjutnya akan disajikan karakteristik dan tantangan pendidik dan peserta didik dalam melaksanakan pembelajaran online.

\section{Tantangan Pendidik dan Peserta Didik dalam Pembelajaran Online.}

Secara umum karakteristik pendidik dalam pembelajaran online yaitu sebagai moderator dan fasilitator selama kegiatan pembelajaran (pasif). Namun Dabbagh dan Bannan-Ritland (2015:47) menjelaskan secara spesifik tentang keterampilan pendidik dalam pembelajaan online, yaitu:

1. Keterampilan dalam memahami karakteristik dan kebutuhan peserta didik dalam pembelajaran online.

2. Keterampilan mengadopsi berbagai model pembelajaran dengan mempertimbangkan kebutuhan dan harapan dari berbagai karakterr peserta didik.

3. Keterampilan dalam memahami teknologi belajar sebagai media penyampai materi belajar.

4. Keterampilan dalam mengembangkan materi, serta mampu menjadi fasilitator.

Berbeda dengan karakteristik dan kompetensi pendidik dalam pembelajaran online, peserta didik memiliki karakter utama sebagai pebelajar mandiri (aktif). Secara spesifik Dabbagh dan Bannan-Ritland (2005:49) merumuskan beberapa keterampilan peserta didik dalam pembelajaran online, yaitu:

1. Keterampilan dalam penggunaan teknologi belajar.

2. Menunjukkan kebutuhan akan afiliasi (hubungan antar peserta didik)

3. Menghargai dan memahami esensi dalam berinteraksi dan berkolaborasi.

4. Memiliki akademik yang kuat mengenai konsep-diri.

5. Memiliki pengalaman atau keterampilan tentang pembelajaran mandiri.

Munculnya kompetensi baru di atas membuat para pendidik dan peserta didik harus lebih mempersiapkan diri sebelum menerapkan model pembelajarna online, minimal mereka memahami apa yang telah disajikan tentang keterampilan-keterampilan di atas. Dengan kata lain, jika ingin pelaksanaan pembelajaran online berhasil, maka diperlukan persiapan-persiapan matang baik oleh pendidik sebagai fasilitator dan penyedia materi maupun peserta didik sebagai pebelajar mandiri. 
Selanjutnya akan disajikan tentang kerangka desain model pembelajaran terpadu dalam pembelajaran online untuk memberikan sebuah panduan untuk memudahkan bagi pendidik terutama dan sebagai model alternatif agar dapat menghasilakan model pembelajaran online yang sesuai dengan karaktersitik dan kebutuhan peserta didik.

\section{Kerangka desain pembelajaran integratif dalam Pembelajaran Online.}

Integrative Learning Deign Framework for Online Learnig (ILDF) atau Kerangka desain pembelajaran terpadu untuk model pembelajaran online, yang terdapat pada Gambar 1, terdiri dari dua pola utama.

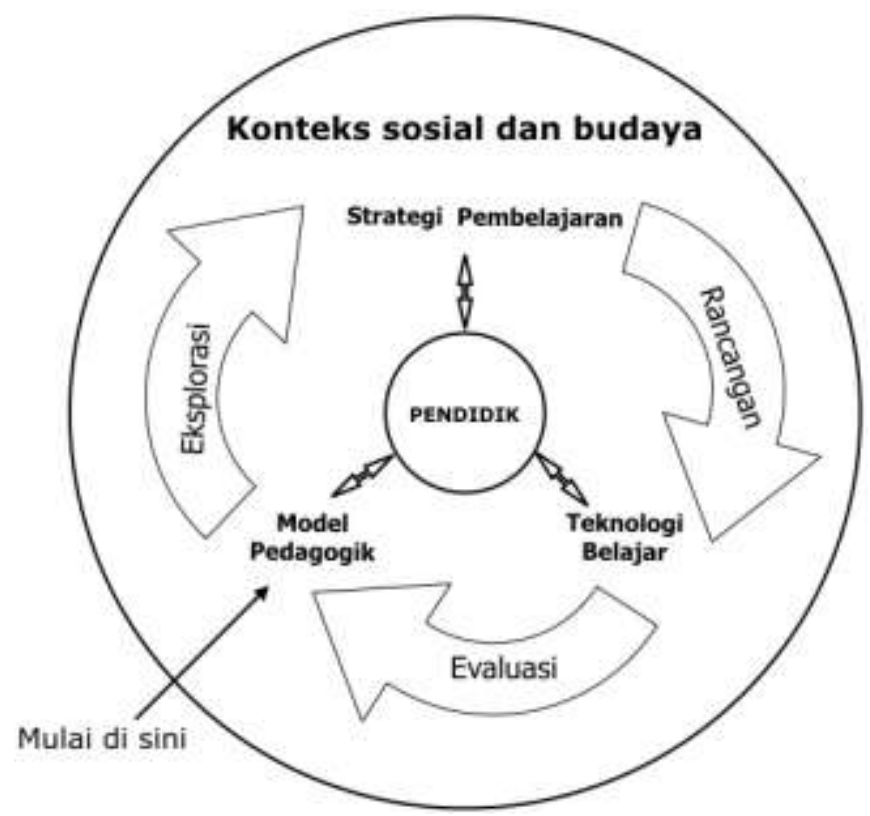

Gambar 1. Kerangka desain pembelajaran Terpadu dalam Pebelajaran Online. (Dabbagh dan Bannan-Ritland (2005:49)

Pola pertama, komponen model pembelajaran online yang terdiri dari model pedagogik, strategi pembelajaran, dan teknologi belajar. Sementara itu, pola kedua merupakan proses sistematik pengembangan model pembelajaran online yang terdiri dari eksplorasi, rancangan, dan evaluasi. Untuk lebih jelasnya, berikut ini akan disajikan uraian kedua pola tersebut dengan sedikit deskripsi sederhana.

\section{A. Komponen dalam Model Pembelajaran Online.}

Tiga komponen utama dalam pembelajaran online yang dapat mendorong kegiatan belajar dan interaksi bermakna yaitu terdiri dari model pedagogik, strategi pembelajaran, dan teknologi belajar (lihat pada Gambar 2). 


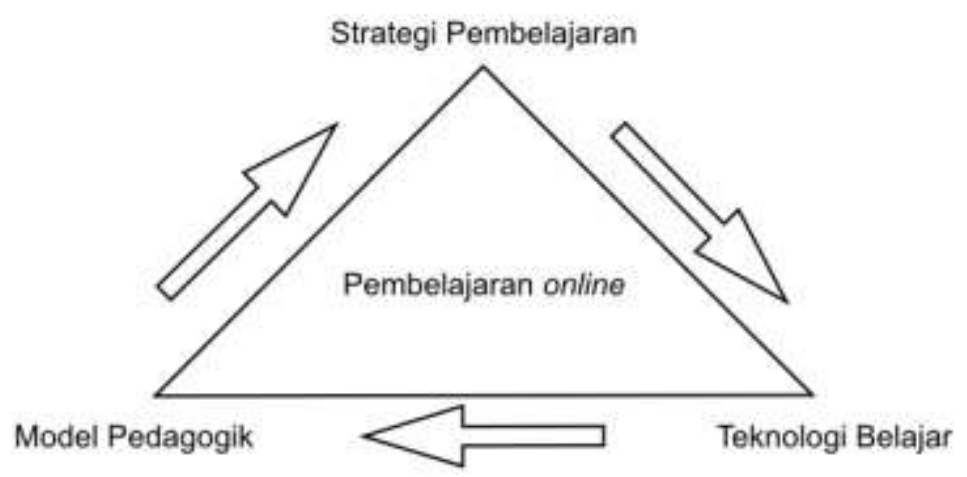

Gambar 2. Tiga komponen utama Model Pembelajaran Online

(Dabbagh dan Bannan-Ritland (2005:16)

1. Model pedagogik.

Model pedagogik dapat di deskripsikan sebagai pandangan terhadap proses pembelajaran, yaitu model atau konstruksi teoritis yang berasal dari teori-teori belajar yang dapat di implementasikan ke dalam strategi pembelajaran yang spesifik (Dabbagh dan Bannan-Ritland, 2005:49). Dalam memahami model pedagogik hal pertama yang harus dipahami adalah cara bagimana individu belajar dan bagaimana sebuah pengetahuan dibangun, disimpan, dan kemudian ditarik kembali. Untuk itu, berikut ini akan disajikan uraian sederhana tentang teori belajar yang dapat memberikan pemahaman terhadap model pedagogic (Harasim, 2012: 37).

a. Pedagogik teori behavioris.

Pedagogik behavioris ditujukan untuk mendorong dan memodifikasi perilaku yang dapat diamati, sehingga belajar dapat diartikan sebagai perubahan pengetahuan dan keterampilan yang dapat diamati. Contoh teknik behavioris yaitu, memberikan hukuman dan penghargaan, dimana ketika peserta didik yang menunjukkan hasil sesuai maka akan memperoleh penghargaan, sedangkan peserta didik yang menunjukkan hasil kurang sesuai maka akan memperoleh hukuman.

b. Pedagogik teori kognitivis.

Pedagogik kognitivis lebih menekankan pada pembelajaran yang preskiptif. Hal ini menakankan pada pandangan dasar bahwa prilaku individu dapat diprediksi, dimana stimulus tertentu akan menghasilakan hasil belajar tertentu, artinya sesuai dengan yang diharapkan. Oleh karena itu, tugas desainer pembelajaran adalah mengidentifikasi stimulus belajar yang mampu menghasilkan hasil belajar tertentu. Sebab, mereka menggunakan dasar pertimbangan teori pemrosesan informasi dan schema. Dengan kata lain, model ini beranggapan bahwa tidak ada stimulus belajar yang paling baik, akan tetapi setiap jenis stimulus belajar akan menghasilkan setiap jenis hasil belajar tertentu.

c. Pedagogik teori konstruktivis.

Pedagogik konstruktivis memandang pada peserta didik secara aktif membangun pengetahuannya sendiri. Oleh karena itu, model ini berfokus pada peserta didik dan kelompok peserta didik, berbeda dengan model behavioris dan kognitivis yang berfokus pada pendidik atau desainer pembelajaran, sehingga model ini menekankan pada peran peserta didik sendiri dalam membangun pengetahuannya. Contoh teknik behavioris adalah pembelajaran aktif, belajar dengan melakukan, scaffolding learning, dan belajar berkolaborasi, serta pembelajaran mandiri. 


\section{Strategi pembelajaran.}

Strategi pembelajaran dapat diartikan sebagai teknik dan rencana yang di digunakan oleh pendidik sebagai upaya untuk memfasilitasi dan melibatkan peserta didik dalam kegiatan belajar (Dabbagh dan Bannan-Ritland, 2005:49). Tidak jauh berbeda dengan pendapat tersebut, menurut Carey dan Carey (2009:166) secara umum strategi pembelajaran meliputi pemilihan sistem penyampaian, mengurutkan dan mengelompokkan isi pembelajaran. hingga memilih media untuk penyampaian isi pembelajaran. Oleh karena itu, hasil dari strategi pembelajaran dapat berupa sebuah rencana, metode, atau prosedur belajar yang dapat digunakan untuk memperoleh hasil belajar spesifik.

Dalam memahami strategi pembelajaran yang terdapat pada komponen model pembelajaran online, akan disajikan contoh strategi pembelajaran yang sesuai dengan model pedagogik konstruktivis. Adapun contoh startegi pembelajaran yang dapat menunjang model pedagogik konstructivis (Dabbagh dan Bannan-Ritland, 2005:206) yaitu, mendorong aktivitas belajar yang riil, mendorong keterampilan pemecahan masalah, mendorong keterampilan berkolaboasi dan bersosial, mendorong scaffolding, mendorong keterampilan belajar mandiri.

3. Teknologi belajar online.

Teknologi belajar online dapat dikategorikan kedalam komunikasi asynchronous dan synchronous, hypermedia dan multimedia, serta web (Dabbagh dan Bannan-Ritland, 2005:16). Dalam memahami teknologi belajar dengan mudah, artikel ini akan menyajikan gambaran teknologi belajar menurut Bates dan Poole, yang dapat dimanfaatkan dalam pembelajaran online (Smith, 2006: 9). Perhatikan Tabel 2.

Tabel 2. Teknologi Belajar Online

\begin{tabular}{|c|c|c|c|}
\hline \multicolumn{4}{|c|}{ TEKNOLOGI BELAJAR ONLINE } \\
\hline \multicolumn{2}{|c|}{ PENYIARAN } & \multicolumn{2}{|c|}{ KOMUNIKASI } \\
\hline Sinkron & Tidak Sinkron & Sinkron & Tidak Sinkron \\
\hline $\begin{array}{l}\text { Webcasitng } \\
\text { Streaming audio } \\
\text { Streaming video }\end{array}$ & $\begin{array}{l}\text { Portal web } \\
\text { CD-R } \\
\text { VCD } \\
\text { Learning objects } \\
\text { Multimedia klip } \\
\text { Blogs. }\end{array}$ & $\begin{array}{l}\text { Chat } \\
\text { Konferensi web } \\
\text { Voice iver IP }\end{array}$ & $\begin{array}{l}\text { E-mail } \\
\text { Diskusi forum. }\end{array}$ \\
\hline
\end{tabular}

Tabel 2, terdiri dari penyiaran atau alat pengiriman materi belajar dan komunikasi atau alat komunikasi antara pendidik dan peserta didik. Dalam penyiaran maupun komunikasi terdapat dua jenis metode, yaitu sinkron dan tidak sinkron. Sinkron secara sederhana dapat diartikan sebagai pengoprasian kegiatan belajar secara bersama, di mana peserta didik diharuskan berpartisipasi secara serentak dalam waktu yang telah ditentukan. Sedangkan metode tidak sinkron adalah pengoprasian kegiatan belajar yang tidak serentak, di mana peserta didik dapat memilih waktu, waktu yang sesuai dengan peserta didik. Sebagai tambahan, teknologi belajar dalam pembelajaran online dapat dikategorikan kedalam perannya sebagai mengelola program pembelajaran, mengembangkan program pembelajaran, dan pengiriman program pembelajaran (Carliner, 2014: 11). 


\section{B. Proses Sistematis dalam Mengembangkan Pembelajaran Online.}

Dalam mengembangkan model pembelajaran online terdapat tiga tahapan utama, yaitu tahap eksplorasi, rancangan, dan evaluasi (Dabbagh dan Bannan-Ritland, 2005:114). Perhatikan Gambar 3.

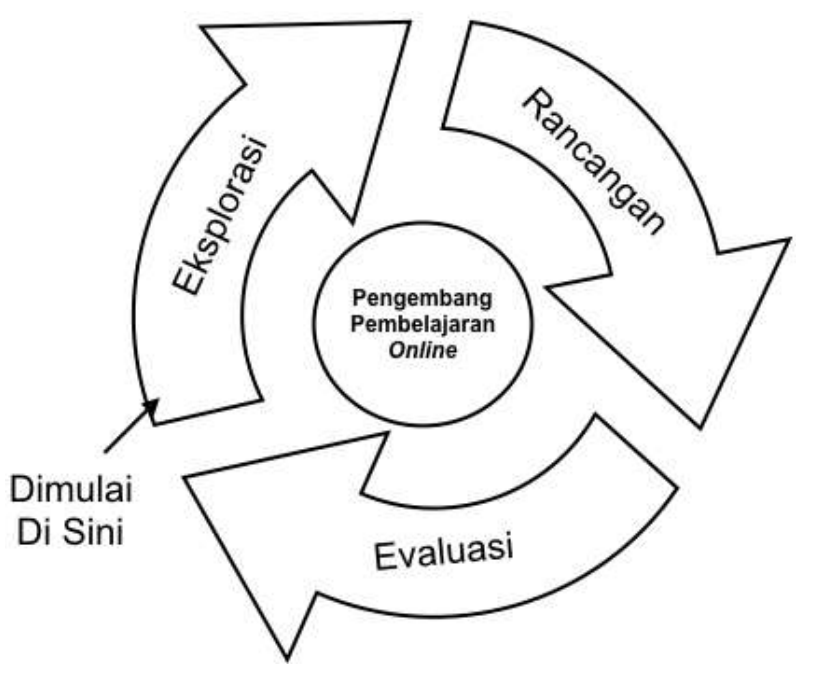

Gambar 3. Proses sistematis pengembangan pembelajaran online

1. Tahap pertama yaitu eksplorasi di mana kegiatan utamanya adalah mengidentifikasi dan memeriksa informasi yang berkaitan dengan kondisi pembelajaran, termasuk peserta didik, (Dabbagh dan Bannan-Ritland, 2005:115). Dengan kata lain, pendidik atau pengembang pembelajaran online memiliki tugas utama dalam mengumpulkan dan mengidentifikasi informasi yang berkaitan dengan karakteristik peserta didik, lingkungan, materi, dan tujuan belajar, yang pada ahirnya informasi tersebut akan mengantarkan pendidik atau pengembang pembelajaran online dalam memilih strategi yang sesuai dengan kebutuhan peserta didik.

2. Tahap kedua yaitu perancangan dimana kegiatan utamanya adalah memetakan informasi yang didapat dalam tahap eksplorasi tentang tujuan, proses, materi belajar dengan model pedagogik yang sudah ada, dan juga mempertimbangkan model pedagogik yang akan diplih, sehingga dapat dijadikan sebagai bahan pertimbangan dalam menentukan strategi pembelajaran online yang sesuai dengan kebutuhan peserta didik (Dabbagh dan Bannan-Ritland, 2005:115). Dengan kata lain, tahap ini mengharuskan pendidik dan pengembang pembelajaran menghasilkan strategi pembelajaran yang efektif melalui analisa terhadap hasil eksplorasi terhadap model pedagogik atau teori belajar, yang dapat menghasilkan strategi pembelajaran yang spesifik dan dijadikan sebagai bahan pertimbangan dalam memilih teknologi belajar yang dapat dievaluasi pada tahap selanjutnya.

3. Tahap ketiga yaitu evaluasi di mana kegiatan utamanya adalah menentukan tujuan, hasil yang diharapkan, dan cara mengevaluasi desain pembelajaran online, menggabungkan evaluasi formatif dengan siklus revisi yang menghasilkan keefektifitasan hasil penerapan pembelajaran online (Dabbagh dan Bannan-Ritland, 2005:115). Dengan kata lain, pendidik atau desainer pembelajaran harus mampu mengaplikasikan kemampuan pengampilan keputusan yang baik dengan mempertimbangkan faktor yang berkaitan dengan konteks pembelajaran. Selain itu, 
melalui evaluasi pendidik dan desainer pembelajaran mampu mengetahui efektifitasan desainnya dari hasil evaluasi formatif dan biasanya menggunakan para ahli.

\section{SIMPULAN}

Artikel ini telah menghasilkan kerangka desain pembelajaran terpadu dalam pembelajaran online, kerangka tersebut merupakan salah satu model alternatif yang dapat digunakan pendidik dan desainer pembelajaran dalam mendesain dan mengembangkan model pembelajaran online yang efektif. Model ini tidak hanya memperhatikan faktor sosial budaya yang biasanya tidak terfikirkan oleh para desain pembelajaran online, akan tetapi model ini juga menyajikan uraian tugas pendidik dan desainer pembelajaran dalam pembelajaran online sacara komprehensif.

Oleh karena itu, kerangka desain pembelajaran terpadu dalam pembelajaran online ini tidak hanya dapat memberikan kemudahan bagi pendidik dan desainer pembelajaran dalam merancang model pembelajaran online, akan tetapi memudahkan peserta didik dalam membangun pengetahuannya dan berinteraksi. Sebab, model ini memiliki tahap eksplorasi, perancangan, dan evaluasi yang dapat mewujudkan pembelajaran online yang sesuai dengan kebutuhan peserta didik.

Sehingga, dengan adanya kerangka desain pembelajaran terpadu dalam pembelajaran online ini tidak ada lagi kegiatan belajar mandiri yang tidak terstruktur yang dilakukan oleh peserta didik selama melaksanakan pratek kerja industri. Karena model ini dapat diadopsi oleh pendidik, desainer pembelajaran, dan praktisi pendidikan yang ingin merancang model pembelajaran online yang efektif.

\section{REFERENSI}

Ally, M. (Eds). (2008). The Theory and Practice of Online Learning, Second Edition. Alberta: AU Press.

Bukit, M. (2014). Strategi dan Inovasi Pendidikan Kejuruan. Bandung: Alfabet.

Carey W. Dick dan Carey, L \& Carey, J (2009). The Systematic Design of Instruction. New Jersey: Pearson.

Carliner, S. (2004). An Overview of Online Learning: Second Edition. Massachusetts: HRD Press, Inc.

Dabbagh, N \& Bannan-Ritland, B. (2005). Online Learning: Concepts, Strategies, and Application. New Jersey: Pearson Education, Inc.

Diningrat, SWM. (2016). Pengembangan Bahan Ajar Online Pada Mata Pelajaran Matematika untuk Menigkatkan Hasil Belajar Siswa Prakerin Kelas XI Di SMK Sunan Giri Menganti Gresik. Skripsi.

Ellen, E \& Seaman, J. (2007). Online National: Five Years of Growth in Online Learning. Needham: Sloan Consortium.

Harasim, L. (2012). Learning Theory and Online Technologies. New York: Routledge.

Smith, S. (2006). Web-Based Instruction A Guide for Libraries: Second Edition. Chicago: American Library Association. 